\title{
Selective arterial embolization as neoadjuvant treatment in hip pseudotumors
}

\author{
Kalça psödotümörlerinde neoadjuvan tedavi olarak selektif arteriyel embolizasyon
}

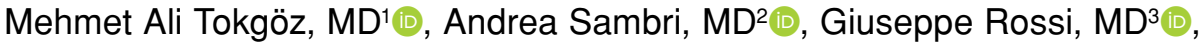

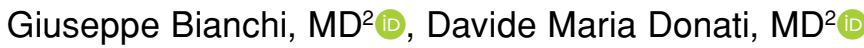 \\ 1Department of Orthopedics and Traumatology, Gazi University Faculty of Medicine, Ankara, Turkey \\ ${ }^{2}$ Department of Orthopedic Oncology, Istituto Ortopedico Rizzoli, Bologna, Italy \\ ${ }^{3}$ Department of Radiology and Interventional Angiographic Radiology, Istituto Ortopedico Rizzoli, Bologna, Italy
}

\begin{abstract}
Objectives: This study aims to investigate the significance of selective arterial embolization (SAE) as neoadjuvant for the treatment of pseudotumor (PT) associated with hip arthroplasty and present our case series including all the known bearing techniques.

Patients and methods: This retrospective study included 16 patients (9 males, 7 females; mean age 75.5 years; range, 55 to 87 years) affected by hip PT. Seven patients were treated only surgically without any adjuvant treatment (group A), while nine patients were performed preoperative SAE (group B). Pseudotumors were grouped according to magnetic resonance imaging and computed tomography (CT) classifications. Durations of all operations and number of blood units given intra- and postoperatively were recorded.
\end{abstract}

Results: Although embolization did not change the amount of intraoperative bleeding $(\mathrm{p}=0.619)$, a common vascular network leading to PT was observed in all patients in angiography. Group A's mean duration of operation was shorter than group B $(\mathrm{p}=0.03)$; however, this condition was attributed to larger and more complex lesions of patients who underwent embolization. According to CT classification, blood loss was more and duration of operation was longer in severe stages $(\mathrm{p}=0.046$ and $\mathrm{p}=0.035$, respectively).

Conclusion: Successful demonstration of vascular network in patients with PT strengthens the idea that SAE technique may be used particularly in severe cases according to CT classification. Our findings suggest that PT may develop in all commonly used bearings.

Keywords: Pseudotumor of hip, selective arterial embolization, total hip arthroplasty.
$\ddot{O} Z$

Amaç: Bu çalışmada kalça artroplastisi ile ilişkili psödotümör (PT)'ün tedavisinde neoadjuvan olarak selektif arteriyel embolizasyon (SAE)'un önemi araştırıldı ve bilinen tüm taşı1cı teknikleri içeren olgu serimiz sunuldu.

Hastalar ve yöntemler: $\mathrm{Bu}$ retrospektif çalışmaya kalça PT'sinden etkilenen 16 hasta (9 erkek, 7 kadın; ort. yaş 75.5 yıl; dağılım, 55-87 yıl) dahil edildi. Yedi hasta herhangi bir neoadjuvan tedavi olmaksızın sadece cerrahi ile tedavi edilirken (grup A) dokuz hastaya ameliyat öncesi SAE uygulandı (grup B). Psödotümörler manyetik rezonans görüntüleme ve bilgisayarlı tomografi (BT) sınıflandırmasına göre gruplandırıldı. Tüm ameliyatların süreleri ve ameliyat sırasında ve sonrasında verilen kan ünitelerinin sayısı kaydedildi.

Bulgular: Embolizasyon ameliyat sırasında kanama miktarını değiştirmese de $(p=0.619)$ anjiyografide tüm hastalarda PT'ye giden yaygın bir vasküler ağ izlendi. Grup A'nın ortalama ameliyat süresi grup B'den daha kısa idi $(\mathrm{p}=0.03)$ ancak bu durum embolizasyon uygulanan hastaların daha büyük ve kompleks lezyonlara sahip olmasına bağlandı. Bilgisayarlı tomografi sınıflandırmasına göre, şiddetli evrelerde kan kaybı daha fazla ve ameliyat süresi daha uzun idi (sırasıyla $\mathrm{p}=0.046$ ve $\mathrm{p}=0.035$ ).

Sonuç: Psödotümörlü hastalarda vasküler ağın başarılı şekilde gösterilmesi, SAE tekniğinin özellikle BT sınıflandırmasına göre daha ciddi olgularda kullanılabileceği fikrini güçlendirmektedir. Bulgularımız PT'nin yaygın şekilde kullanılan tüm taşıyıcılarda gelişebileceğine işaret etmektedir.

Anahtar sözcükler: Kalça psödotümörü, selektif arteriyel embolizasyon, total kalça artroplastisi.

Received: January 24, 2019 Accepted: February 19, 2019

Correspondence: Mehmet Ali Tokgöz, MD. Gazi Üniversitesi Tıp Fakültesi Ortopedi ve Travmatoloji Anabilim Dalı, 06500 Beşevler, Ankara, Turkey Tel: +90 312 - 2025528 e-mail: m.alitokgoz@gmail.com 
Total hip arthroplasty (THA) is a common procedure in orthopedics; nevertheless, many complications are possible. ${ }^{[1-3]}$ One of the most common delayed periprosthetic complications is pseudotumor (PT), which is a tumor-like granulomatous lesion or destructive cystic lesion that can develop near THA. ${ }^{[4,5]}$ It is generally caused by prosthesis debris. Pseudotumor is frequently observed in metal-on-metal bearings, but can also develop in other bearings. ${ }^{[6-8]}$ These masses can be small or large, solid or cystic. They tend to worsen progressively, both in size and pain. ${ }^{[9]}$

Two different classifications (Table I $)^{[10,11]}$ based on magnetic resonance imaging (MRI) and computed tomography (CT) have been proposed to describe PT. These classifications take into account both the composition and the location of PT, including its potential extension inside the abdominal compartment, and can be used to predict the difficulty and risk of complications of the surgery.

There is still no consensus on the best treatment of PT associated to THA and the outcome of surgical treatment is generally unsatisfying. Excision of PT can be extremely demanding as it can bleed excessively.

Selective arterial embolization (SAE) has been widely used in bone and soft tissue sarcomas either as main treatment or neoadjuvant to surgery with excellent results, ${ }^{[12,13]}$ in order to facilitate surgical procedures and reduce bleedings. ${ }^{[14-16]}$ In this study, we aimed to investigate the significance of SAE as neoadjuvant for the treatment of PT associated with hip arthroplasty and present our case series including all the known bearing techniques.

\section{PATIENTS AND METHODS}

This retrospective study included 16 patients ( 9 males, 7 females; mean age 75.5 years; range, 55 to 87 years) affected by PT of the hip and treated at Istituto Ortopedico Rizzoli, Bologna, Italy, between October 2011 and December 2016. The study protocol was approved by the Istituto Ortopedico Rizzoli Ethics Committee. A written informed consent was obtained from each patient. The study was conducted in accordance with the principles of the Declaration of Helsinki.

Seven patients were treated only surgically without any adjuvant treatment (group A), while nine patients received preoperative SAE (group B). Patients' preoperative hemoglobin values and bearing surfaces were reported in Table II. Pseudotumors characteristics were classified according to preoperative imaging, using both $\mathrm{MRI}^{[11]}$ and $\mathrm{CT}^{[10]}$ (Table II, Figure 1).

Mean duration between THA implantation and SAE was 122 months (range, 60 to 227 months). At the time of preoperative evaluation, 10 patients had pain at rest, while others had only pain at hip movements. Group B included most of the patients affected by larger and more aggressive PTs (grade I according to MRI classification and grade $\mathrm{V}$ according to $\mathrm{CT}$ classification).

TABLE I

Radiological classification systems of pseudotumors

\begin{tabular}{|c|c|c|c|}
\hline \multicolumn{4}{|c|}{ Magnetic resonance imaging classification ${ }^{[11]}$} \\
\hline Grade I & \multicolumn{3}{|c|}{ Thin-walled cystic mass (cyst wall $<3 \mathrm{~mm}$ ) } \\
\hline Grade II & \multicolumn{3}{|c|}{ Thick-walled cystic mass (cyst wall $>3 \mathrm{~mm}$, but less than the diameter of the cystic component) } \\
\hline Grade III & \multicolumn{3}{|c|}{ A predominantly solid mass } \\
\hline \multicolumn{4}{|c|}{ Computed tomography classification ${ }^{[10]}$} \\
\hline Class & Grade & Description & \\
\hline \multirow[t]{2}{*}{ A } & I & Normal & Thickening of the capsule up to $6 \mathrm{~mm}$ \\
\hline & II & Reactive & $\begin{array}{l}\text { Capsule thickening over } 6 \mathrm{~mm} \text { without bulging posterior, not exceeding the } \\
\text { neck of the prosthesis and without eccentric capsule enlargement }\end{array}$ \\
\hline B & II & Mild & Bulging of the capsule anterior and posterior \\
\hline \multirow[t]{2}{*}{ C } & IV & Moderate & $\begin{array}{l}\text { Eccentric capsular enlargement predominantly inferomedial of the } \\
\text { prosthetic head }\end{array}$ \\
\hline & V & Severe & $\begin{array}{l}\text { Bursitis mimicker with extensive filling of the subtrochanteric bursa } \\
\text { posterior and/or with filling of the iliopectineal bursa anterior with potentia } \\
\text { extension in the abdominal compartment }\end{array}$ \\
\hline
\end{tabular}


TABLE II

Patients and disease characteristics

\begin{tabular}{|c|c|c|c|c|}
\hline & \multicolumn{2}{|c|}{$\begin{array}{c}\text { Group A } \\
\text { (Surgery) }(n=7)\end{array}$} & \multicolumn{2}{|c|}{$\begin{array}{c}\text { Group B } \\
\text { (Surgery + embolization) }(n=9)\end{array}$} \\
\hline & $\mathrm{n}$ & Mean & $\mathrm{n}$ & Mean \\
\hline Age (year) & & 70.6 & & 81.4 \\
\hline $\begin{array}{l}\text { Magnetic resonance imaging } \\
\text { Grade I } \\
\text { Grade I } \\
\text { Grade III }\end{array}$ & $\begin{array}{l}2 \\
4 \\
1\end{array}$ & & $\begin{array}{l}6 \\
1 \\
2\end{array}$ & \\
\hline $\begin{array}{l}\text { Computed tomography grades } \\
\text { Grade I } \\
\text { Grade II } \\
\text { Grade III } \\
\text { Grade IV } \\
\text { Grade V }\end{array}$ & $\begin{array}{l}0 \\
0 \\
6 \\
0 \\
1\end{array}$ & & $\begin{array}{l}0 \\
0 \\
1 \\
2 \\
6\end{array}$ & \\
\hline $\begin{array}{l}\text { Bearings } \\
\text { Metal-on-metal } \\
\text { Metal-on-polyethylene } \\
\text { Others (Cer-Cer, Cer-Poly) }\end{array}$ & $\begin{array}{l}4 \\
1 \\
2\end{array}$ & & $\begin{array}{l}1 \\
7 \\
1\end{array}$ & \\
\hline Preoperative $\mathrm{Hb}(\mathrm{g} / \mathrm{dL})$ & & 12.2 & & 11.8 \\
\hline
\end{tabular}

Cer-Cer: Ceramic-on-ceramic; Cer-Poly: Ceramic-on-polyethylene.

Digital subtraction angiography (DSA) and SAE were performed by inserting a catheter through the common femoral artery (Seldinger technique) under local anesthesia. Glubran 2 surgical glue (N-2-butyl-cyanoacrylate) was mixed with lipiodol ultrafluid (dilution 33\%) and the compound was injected "sandwiched" with glucosate solution 5\% to prevent polymerization with blood. ${ }^{[17]}$

The procedure was divided into three steps. The first step was a DSA of the anatomical site of the PT to obtain a vascular map of the pathological vessels
(Introducer, Pigtail, Cobra, Simmons). The second step was selective catheterizations (coaxial catheter system) and subsequent embolization of the lesion feeding vessels; after every single embolization a control DSA was performed to verify the quality of the occlusion and the residual pathological bloodstream. At the end of the procedure (third step), another DSA of the PT was performed to evaluate the efficacy of the occlusion. All procedures were carried out with a Philips Integris V3000 Cesar-SCP-Visub angiographic system (Philips Medical Systems, Eindhoven, the Netherlands) (Figure 2).
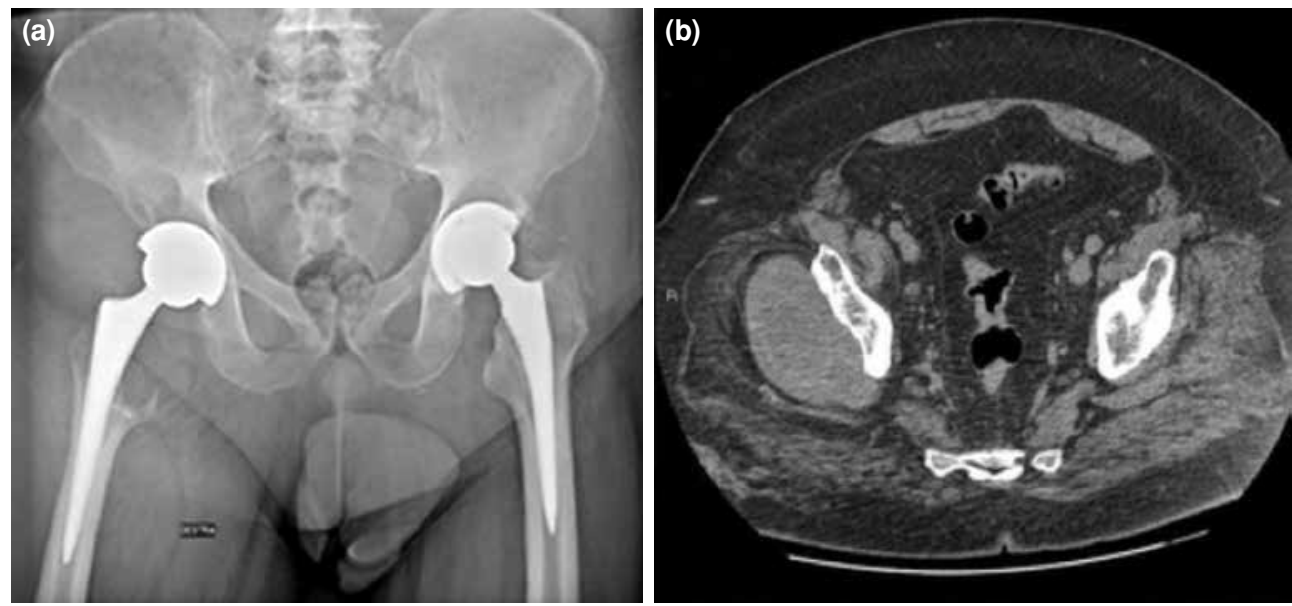

Figure 1. Large pseudotumor of right hip in a 66-year-old male patient with bilateral metal-onmetal total hip arthroplasty. Preoperative X-ray (a) and computed tomography (b) of pelvis showing pseudotumor around right hip. 


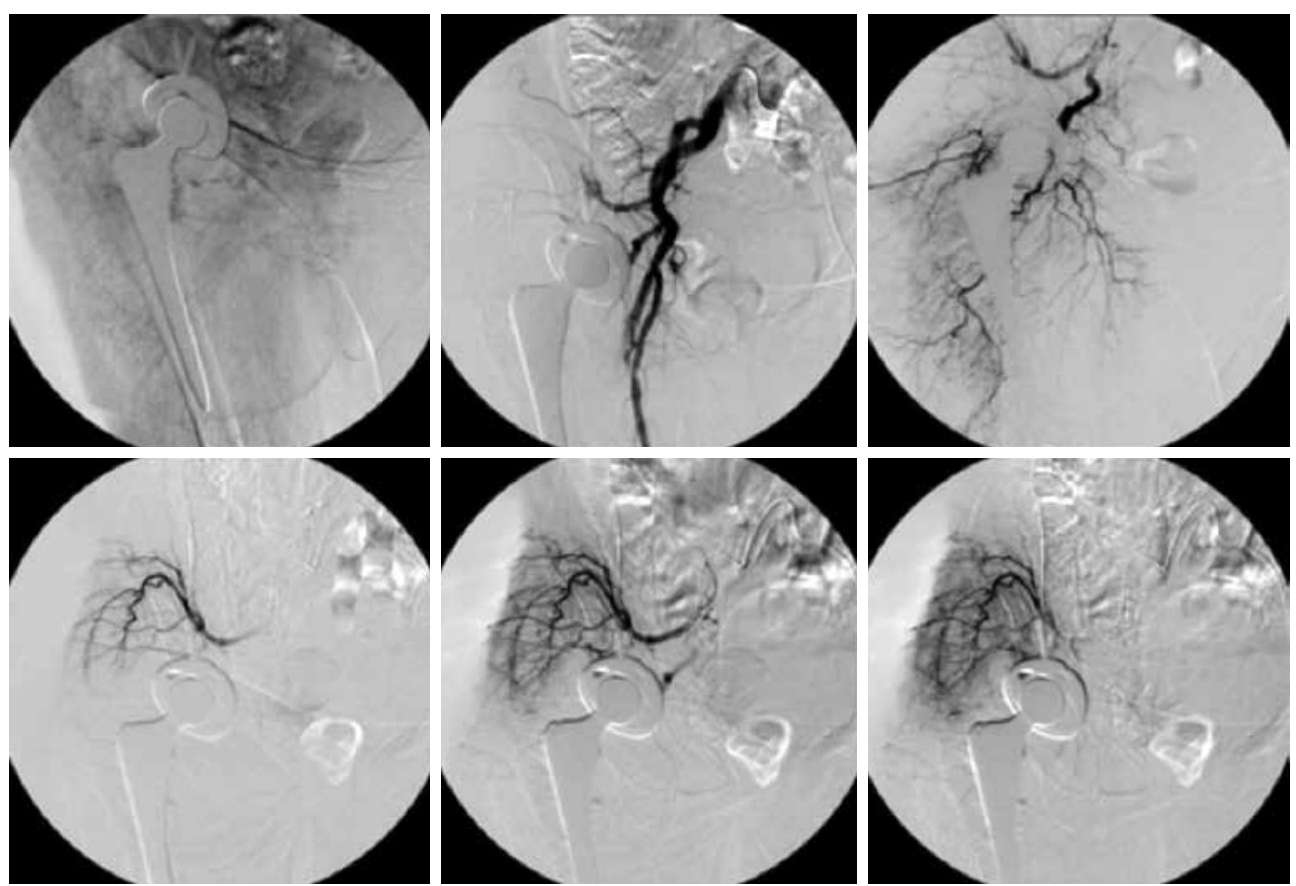

Figure 2. Different stages of digital subtraction angiography in a hip pseudotumor patient, respectively. Strong vascular supply of lesion is visible after injection of radiopacifier.

In three cases in which an aseptic loosening was suspected, a one-stage exchange procedure was performed. In four other cases in which a septic loosening was supposed, THA was removed and a two-stage procedure was planned. All surgical procedures were performed with an anterior approach to the hip in a semi-lateral position. In the case of intrapelvic PT, the approach was extended proximally toward an ileofemoral approach to get that area exposed (Figure 3). In all the cases, the PT was excised completely with marginal margins, like a sarcoma, removing entirely the pseudotumoral wall. Samples were taken for both histological and microbiological tests. The durations of all operations were recorded and blood losses were estimated using the number of blood units which were given intraand postoperatively.

\section{Statistical analysis}

All analyses were completed using the IBM SPSS Statistics for Windows, Version 22.0 (IBM Corp., Armonk, NY, USA). Differences between the results were assessed by the t-test. Statistical analysis was considered significant when $\mathrm{p}<0.05$.
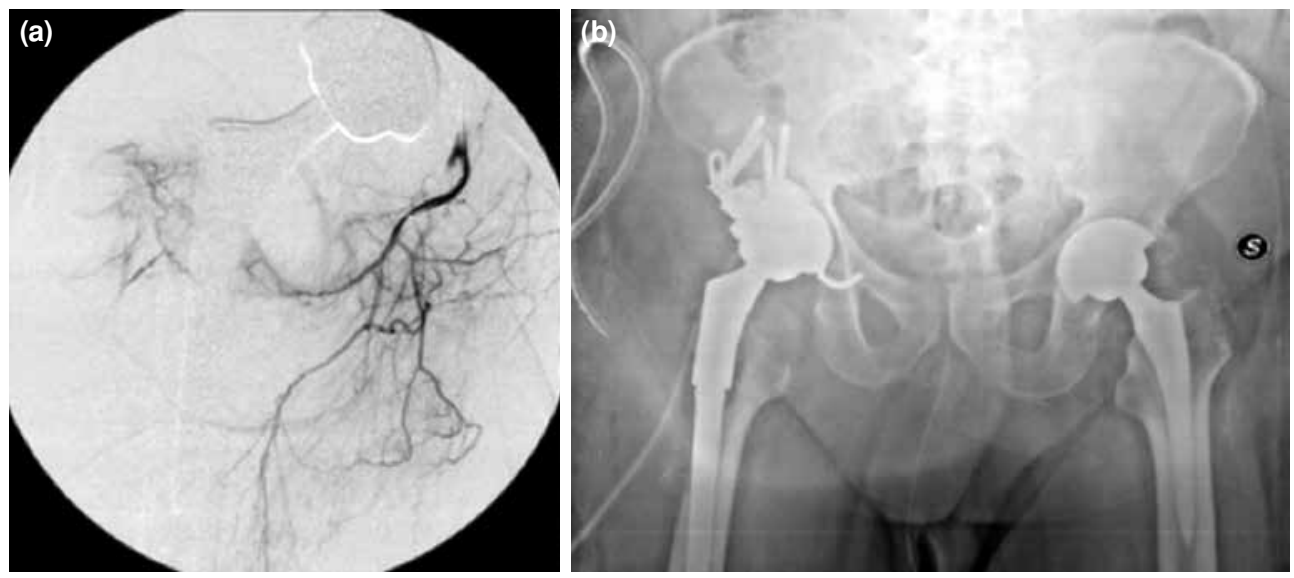

Figure 3. (a) Angiography showing high vascularization of pseudotumor. (b) Postoperative X-ray of pelvis showing right hip arthroplasty after revision surgery. 


\section{RESULTS}

No complications were observed. All patients in group B were found to have feeding vessels at DSA, which were closed using SAE. One patient underwent embolization twice at three-month intervals and PT was excised after the second SAE. Spongostan and Glubran 2 were used for embolization in two and seven patients, respectively.

Prosthesis loosening was detected in seven patients on the cup side and in one patient at the femoral side. No evidence of loosening was observed in any other patient.

Twelve patients underwent a single-stage prosthesis exchange, while four patients underwent a two-stage revision surgery. One patient did not receive any reconstruction after the first-stage procedure due to medical comorbidities rendering him unfit for anesthesia and remained with a cement spacer in situ. Septic loosening was confirmed in four patients, but microbiological cultures were positive in only two patients (methicillin-resistant Staphylococcus aureus in one patient and methicillin-sensitive coagulasenegative Staphylococcus in the other one).

Embolization did not change the amount of intraoperative bleeding (four and 3.6 blood units in group A and B, respectively; $\mathrm{p}=0.619$ ). A shorter mean duration of operation was observed in group A compared to group B (106 and 181 minutes, respectively; $\mathrm{p}=0.03)$. According to $\mathrm{CT}$ classification, blood loss was more and duration of operation was longer in severe stages $(\mathrm{p}=0.046$ and of $\mathrm{p}=0.035$, respectively).

At final follow-up (mean 13 months, range, 7 to 37 months), none of the patients had recurrence of PT. Two patients developed a postoperative wound problem, but no additional intervention was necessary.

\section{DISCUSSION}

Pseudotumor of the hip is a rare but severe complication of THA. Main therapeutic approaches include one or two-stage revision procedures in association to excision of PT. ${ }^{[9,18,19]}$ In addition, new methods have been proposed to facilitate PT surgeries and prevent recurrence. For example, a titanium sleeve was used in association to the cup to prevent PT formation, while short-term results were not successful. ${ }^{[20]}$

Selective arterial embolization is a minimally invasive technique which has been widely used as an adjuvant treatment of bone and soft tissue tumors. ${ }^{[1,21]}$ to reduce intraoperative and postoperative bleeding; nevertheless, to the best of our knowledge, its use in PT surgery has never been described before.

In the present series, DSA showed that all PTs in group B received feeding vessels. Even though previous studies reported that $\mathrm{PT}$ can be avascular, ${ }^{[22,23]}$ they were examined only with Doppler ultrasound. Preoperative angiography may provide important information about femoral vessels that can be compressed by the PT and help in the diagnosis of a possible thrombosis. ${ }^{[24,25]}$

We found that preoperative embolization did not reduce the amounts of blood loss or durations of operation in our study group. Nevertheless, it should be considered that SAE was mostly used in more severe PTs thus representing a selection bias. Even though the benefits of this technique on blood losses and the durations of operation could not be shown statistically, with the use of preoperative embolization in patients with higher grade PT, we experienced similar results to those observed in lower grades. In particular, SAE allowed to limit blood losses even in more difficult cases of PT with an intraabdominal extension.

In the present study, we reported nine PTs with extension in the abdominal compartment. Pseudotumors often remain subclinical but they may cause neurovascular problems. ${ }^{[26,27]}$ and urological alterations. ${ }^{[28]}$ when there is a pelvic mass. In this wide spreading pattern of PT, SAE can monitor the status of intrapelvic vascular structures and the potential intraabdominal feeding vessels of PT are detected and embolized easily preoperatively.

In addition, an investigation of the effect of the severity of disease on these variables demonstrated that the amount of bleeding and duration of operation increased as the grade increased according to the CT classification. This study also showed that the CT-based classification described by Boomsma et al. ${ }^{[10]}$ was useful in evaluating PT as it seems to correlate with difficulties in its excision.

In the literature, the relationship between PT of the hip and bearing techniques has been reported, apart from metal-on-metal (Met-Met). ${ }^{[7,29-31]}$ In this study, we observed PT with different bearings such as metal-on-polyethylene (Met-Poly) in eight patients, ceramic-on-ceramic (Cer-Cer) in two patients, and ceramic-on-polyethylene (Cer-Poly) in one patient. This suggests that PT may develop in all commonly used bearings.

This study has some limitations including its retrospective design and small sample size. However, to the best of our knowledge, this is the first series 
reporting on the use of SAE as an adjuvant therapy to surgery for the treatment of PT around THA. Another important bias is represented by the heterogeneity between the two groups, as most of the patients in group B (SAE + surgery) were affected by more challenging PT.

In conclusion, SAE is a reliable technique with low risk of complications, which may help in reducing blood losses during and after PT excision. This is particularly evident in more challenging cases according to MRI and CT classifications. Even though many patients can be managed properly only with surgery, SAE may be helpful in more challenging cases. Therefore, careful preoperative staging and evaluation are mandatory. Prospective studies with larger sample sizes are required to better understand the SAE efficacy in PT patients.

\section{Declaration of conflicting interests}

The authors declared no conflicts of interest with respect to the authorship and/or publication of this article.

\section{Funding}

The authors received no financial support for the research and/or authorship of this article.

\section{REFERENCES}

1. Houcke JV, Khanduja V, Pattyn C, Audenaert E. The history of biomechanics in total hip arthroplasty. Indian J Orthop 2017;51:359-67.

2. Bakırhan S, Ünver B, Karatosun V. Does preoperative body weight affect early postoperative functional activities in patients with total hip arthroplasty? [Article in Turkish] Eklem Hastalik Cerrahisi 2017;28:188-94.

3. Burge AJ. Total hip arthroplasty: MR imaging of complications unrelated to metal wear. Semin Musculoskelet Radiol 2015;19:31-9.

4. Cadossi M, Tedesco G, Sambri A, Mazzotti A, Giannini S. Hip resurfacing implants. Orthopedics 2015;38:504-9.

5. Nakamura M, Shimakawa $T$, Nakano S, Chikawa $T$, Yoshioka S, Kashima M, et al. Failure rates of Asian-type anatomic medullary locking stemmed metal-on-metal total hip replacement: A cause for adverse tissue reactions to metal debris (ARMD). J Orthop Sci 2016;21:779-85.

6. Slonimsky E, Kushnir T, Kadar A, Menahem A, Grundshtein A, Velekes S, et al. Metal-on-metal hip replacement: MRI signal intensities of different body tissues and their relations to blood metal ion levels. Isr Med Assoc J 2017;19:674-8.

7. Blau YM, Meyers AJ, Giordani M, Meehan JP. Pseudotumor in ceramic-on-metal total hip arthroplasty. Arthroplast Today 2017;3:220-4.

8. Fagotti L, Vicente JR, Miyahara HS, de Oliveira PV, Bernabé AC, Croci AT. Formation of a pseudotumor in total hip arthroplasty using a tribological metal-polyethylene pair. Rev Bras Ortop 2015;50:747-51.

9. Daniel J, Holland J, Quigley L, Sprague S, Bhandari M. Pseudotumors associated with total hip arthroplasty. J Bone Joint Surg [Am] 2012;94:86-93.
10. Boomsma MF, Edens MA, Van Lingen $\mathrm{CP}$, Warringa $\mathrm{N}$, Ettema HB, Verheyen CC, et al. Development and first validation of a simplified CT-based classification system of soft tissue changes in large-head metal-on-metal total hip replacement: intra- and interrater reliability and association with revision rates in a uniform cohort of 664 arthroplasties. Skeletal Radiol 2015;44:1141-9.

11. Hauptfleisch J, Pandit H, Grammatopoulos G, Gill HS, Murray DW, Ostlere S. A MRI classification of periprosthetic soft tissue masses (pseudotumours) associated with metalon-metal resurfacing hip arthroplasty. Skeletal Radiol 2012;41:149-55.

12. Lau V, Sun M, Chu F. Embolisation of hypervascular bone tumours: a pictorial essay with literature review. J Med Imaging Radiat Oncol 2013;57:191-7.

13. Börüban S, Sancak T, Yildiz Y, Sağlik Y. Embolization of benign and malignant bone and soft tissue tumors of the extremities. Diagn Interv Radiol 2007;13:164-71.

14. Ibrahim WH, Safran ZA, Hasan H, Zeid WA. Preoperative and therapeutic embolization of extremities of bone and soft tissue tumors. Angiology 2013;64:151-6.

15. Mavrogenis AF, Rossi G, Rimondi E, Calabrò T, Papagelopoulos PJ, Ruggieri P. Palliative embolization for osteosarcoma. Eur J Orthop Surg Traumatol 2014;24:1351-6.

16. Mavrogenis AF, Rossi G, Calabrò T, Altimari G, Rimondi E, Ruggieri P. The role of embolization for hemangiomas. Musculoskelet Surg 2012;96:125-35.

17. Rossi G, Rimondi E, Bartalena T, Gerardi A, Alberghini M, Staals EL, et al. Selective arterial embolization of 36 aneurysmal bone cysts of the skeleton with N-2-butyl cyanoacrylate. Skeletal Radiol 2010;39:161-7.

18. Cottino U, Dettoni F, Risitano S, Marmotti A, Rossi R. Twostage treatment of a large pelvic cystic pseudotumor in a metal-on-metal total hip arthroplasty. Joints 2017;5:121-4.

19. van der Weegen $W$, Sijbesma T, Hoekstra HJ, Brakel K, Pilot $\mathrm{P}$, Nelissen RG. Treatment of pseudotumors after metalon-metal hip resurfacing based on magnetic resonance imaging, metal ion levels and symptoms. J Arthroplasty 2014;29:416-21.

20. Hjorth MH, Egund N, Mechlenburg I, Gelineck J, Jakobsen SS, Soballe $K$, et al. Does a titanium sleeve reduce the frequency of pseudotumors in metal-on-metal total hip arthroplasty at 5-7years follow-up? Orthop Traumatol Surg Res 2016;102:1035-41.

21. Rossi G, Mavrogenis AF, Facchini G, Bartalena T, Rimondi E, Renzulli M, et al. How effective is embolization with N-2butyl-cyanoacrylate for aneurysmal bone cysts? Int Orthop 2017;41:1685-92.

22. Frisch NB, Wessell NM, Taliaferro K, Van Holsbeeck $\mathrm{M}$, Silverton CD. Ultrasound findings in asymptomatic patients with modular metal on metal total hip arthroplasty. Skeletal Radiol 2017;46:641-9.

23. Muraoka K, Naito M, Nakamura Y, Hagio T, Takano K. Usefulness of ultrasonography for detection of pseudotumors after metal-on-metal total hip arthroplasty. J Arthroplasty 2015;30:879-84.

24. Tamaki Y, Goto T, Tsutsui T, Takasago T, Wada K, Sairyo K. Compression of the femoral vessels by a pseudotumor after metal-on-metal total hip arthroplasty. Case Rep Orthop 2017;2017:2594902.

25. Watanabe H, Takahashi K, Takenouchi K, Sato A, Kawaji $\mathrm{H}$, Nakamura $\mathrm{H}$, et al. Pseudotumor and deep venous thrombosis due to crevice corrosion of the head-neck 
junction in metal-on-polyethylene total hip arthroplasty. J Orthop Sci 2015;20:1142-7.

26. Madan S, Jowett RL, Goodwin MI. Recurrent intrapelvic cyst complicating metal-on-metal cemented total hip arthroplasty. Arch Orthop Trauma Surg 2000;120:508-10.

27. Leung P, Kudrna JC. Growth of an intrapelvic pseudotumor associated with a metal-on-metal total hip arthroplasty after revision arthroplasty causing a femoral nerve neuropathy. Arthroplast Today 2016;2:105-9.

28. Filho NF, de Paiva Luciano A, Vierno B. Pelvic pseudotumor following total hip arthroplasty - case report. Rev Bras Ortop 2014;49:543-9.
29. Campbell J, Rajaee S, Brien E, Paiement GD. Inflammatory pseudotumor after ceramic-on-ceramic total hip arthroplasty. Arthroplast Today 2017;3:83-7.

30. Lakhotia D, Kumar P. Pseudotumour complicated by implant loosening one year after revision ceramic on metal total hip arthroplasty: a case report. J Orthop Case Rep 2017;7:82-6.

31. Li Z, Chen ZF, Liu JX, Liu F. Comparative Mid-term Followup Study of Primary Total Hip Arthroplasty with Metalon-metal and Metal-on-polyethylene Bearings. Orthop Surg 2018;10:312-20. 